\title{
Association of Body Mass Index, Menstrual Flow, Socio-economic and Educational Status with Psychological Stress Levels in Young Age Students
}

\author{
Panneerselvam Periasamy ${ }^{1, *}$, V. Suganthi ${ }^{2}$, Ponmurugan Karuppiah ${ }^{3}$, Senthilkumar Subramanian ${ }^{4}$, Sasikala \\ Gunasekaran ${ }^{5}$, Ramamoorthy Easwaarisiva ${ }^{6}$
}

\begin{abstract}
Panneerselvam
Periasamy ${ }^{1, *}$, V. Suganthi' ${ }^{2}$, Ponmurugan Karuppiah ${ }^{3}$, Senthilkumar Subramanian ${ }^{4}$, Sasikala Gunasekaran ${ }^{5}$, Ramamoorthy

\section{Easwaarisiva ${ }^{6}$}

${ }^{1}$ Research Scholar in Medical Physiology, Vinayaka Mission's Research Foundation (Deemed to be University), Salem, Tamil Nadu, INDIA.

${ }^{2}$ Department of Physiology, Vinayaka Mission's Kirupananda Variyar Medical College \& Hospital, Salem, Tamil Nadu, INDIA.
\end{abstract}

${ }^{3}$ Department of Botany and

Microbiology, College of Science, Riyadh, SAUDI ARABIA.

${ }^{4}$ Department of Biochemistry and Physiology, College of Medicine and Health Science, Jigjiga University, Jigjiga, ETHIOPIA.

${ }^{5}$ Government Erode Medical College and Hospital, Perundurai, Erode, Tamil Nadu, INDIA.

${ }^{6}$ School of Nursing, Government Erode Medical College and Hospital, Perundurai, Erode, Tamil Nadu, INDIA.

*Correspondence

Dr. Panneerselvam Periasamy Research Scholar in Medical Physiology, Vinayaka Mission's Research Foundation (Deemed to be University), Salem, Tamil Nadu, INDIA.

Phone: +919840552040

Email: pannphysio@gmail.com History

- Submission Date: 18-01-2021;

- Review completed: 20-03-2021.

- Accepted Date: 25-03-2021.

DOI : 10.5530/ijcep.2021.8.1.3

Article Available online

http://www.ijcep.org

\section{Copyright}

(C) 2021 Phcog.Net. This is an openaccess article distributed under the terms of the Creative Commons Attribution 4.0 International license.

\begin{abstract}
Background and Aim: To determine the role of factors linked to the presence of perceived stress in students, after evaluating different aspects of mental health in college students. To evaluate and understand the psychological discomfort and reduce burden of it among young aged students. Methods: A total of 291 students fulfilling the inclusion criteria were recruited and Ethical approval was obtained from the institution. Written consent was obtained and all the participants were assured that their identity would be kept confidential. The study participants were asked to complete a questionnaire anonymously consisting of menstrual problems, socio-economic status, educational status and perceived stress scale. Results: Among 291 respondents of this study, 27.15\% students are medical students and $31.62 \%$ are nursing students, $23.02 \%$ of the students are physiotherapy students and $18.21 \%$ are Art and science students. $53.26 \%$ are 1 st and 2 nd year students. $27.15 \%$ of the students have their family income between Rs. $20,000-49,999$ and $24.4 \%$ of the students have their family income between Rs.10,000-19,999. 27.15\% of the student's head of their families are graduates and majority of the head of their families $(67.35 \%)$ are self-employed. Conclusion: This study reveals the relationship between socio-economic status (SES), Body Mass Index (BMI), menstrual problems and psychological stress, which can explain partly due to emotional eating as a coping strategy to overcome the psychological stress.

Key words: Body mass index, Menstrual cycle, Mental stress, Socio-economic status, Young college students, Coping strategy.
\end{abstract}

\section{INTRODUCTION}

Menstruation is the significant indicator for the overall reproductive health of women. Through the existing literature, there was an increasing prevalence of infertility among women, wherein the number of women having difficulty in getting pregnant rose $65 \%$ over the normal in the past decade. ${ }^{[1]}$ Menstrual cycle has a multi-hormonal effect, where the most important cause of menstrual cycle irregularity is functional hypothalamic amenorrhea that was associated with reduced gonadotropin-releasing hormone secretion and hypothalamic-pituitaryadrenal (HPA) axis dysregulation. ${ }^{[2-4]}$ The incidence of these hormonal problems can lead to development of various chronic diseases including, infertility, heart disease, and type 2 diabetes. ${ }^{[5,6]}$ Furthermore, the continuation of menstrual cycle irregularities occurring over long periods may result in early onset of menopause, which increases the risk of heart disease and osteoporosis. Irregular menstruation is found to be affected by several factors including, modifiable risk factors like Body Mass Index (BMI), Psychosocial stress, etc. ${ }^{[7,8]}$ Higher stress levels have been shown to affect the HPA axis activity and the high $\mathrm{BMI}$ has been determined to influence the sex hormone-binding globulin (SHBG), free androgen index (FAI), testosterone, and insulin levels, thereby

The mental health issues among students are of growing concern in todays world as highlighted by many studies. The psychological discomfort of the students will be reflected in several ways including anxiety, stress, depression and sleeping disorders. ${ }^{[11,12]}$ This poor psychological well-being can sometime associate with physical disorders leading to much more deterioration of person health and wellbeing. ${ }^{[13,14]}$ According to the latest research, the preponderance of overweight and obesity has been increasing at a rapid pace over the last few decades, which is linked to psychological stress. ${ }^{[15-19]}$ A progressive rise in prevalence is being observed among the lower socio-economic classes, indicating the increasing socio-economic inequalities in overweight and obesity. Overweight and obesity can have other psychosocial pathways affecting the female wellbeing. ${ }^{[9,10]}$

Cite this article: Panneerselvam P, Suganthi V, Karuppiah P, Subramanian S, Sasikala G, Easwaarisiva R. Association of Body Mass Index, Menstrual Flow, Socio-economic and Educational Status with Psychological Stress Levels in Young Age Students. Int J Clin Exp Physiol. $2021 ; 8(1): 7-10$. 
than in adults due to the individual psychosocial stressors in their lives. ${ }^{[20-22]}$

Not much research is being conducted on the factors like BMI, menstrual flow and socio-economic and educational status and their effect on psychological health of college going students. With this intent, we aim to determine the role of these factors linked to the presence of perceived stress in students, after evaluating different aspects of mental health in college students, which could help to better evaluate and understand the psychological discomfort and reduce burden of it among young aged students.

\section{MATERIALS AND METHODS}

This was a cross sectional study conducted for three months duration (July 2019 to September 2019), in which 291 students from the various healthcare courses of a tertiary care hospital were invited to participate after taking necessary ethical permission form the institution. Female students aged between 18 and 25 years, who were willing to participate in the study were included. Young females with psychiatric problems, chronic illnesses, individuals with any other types of diagnosed pelvic pathologies like pelvic inflammatory disease, fibroids, etc., pregnant and lactating mothers were excluded from the study.

A total of 291 students fulfilling the inclusion criteria were recruited and Ethical approval was obtained from the institution. Written consent was obtained and all the participants were assured that their identity would be kept confidential. The study participants were asked to complete a questionnaire anonymously consisting of menstrual problems, socioeconomic status, educational status and perceived stress scale. This questionnaire was designed by the authors, based on some previous similar studies. PSS10 was used to measure the individual stress levels, scores ranging from $0-13$ were considered to indicate low perceived stress, 14-26 moderate perceived stress, and 27-40 high perceived stress (HPS). ${ }^{[23]}$

\section{Statistical Analysis of Data}

The data collected from the questionnaires was analysed using Statistical Package for Social Sciences (SPSS) for Windows, Version 24.0. The demographic data, menstrual patterns, and incidence of different menstrual disorders in the students were determined by descriptive statistics. The Chi-square test was used to compare the socio-economic status, educational status and stress levels in the students with various menstrual problems, and a $p<0.05$ was considered statistically significant. Correlation between stress and various menstrual problems was carried out via Spearman Pearson correlation coefficient.

\section{RESULTS}

Among 291 respondents of this study, 27.15\% students are medical students and $31.62 \%$ are nursing students, $23.02 \%$ of the students are physiotherapy students and $18.21 \%$ are Art and science students. $53.26 \%$ are 1 st and 2 nd year students. The mean age was $20.00 \pm 1.51$ years and the mean weight was $54.92 \pm 10.28 \mathrm{~kg}$. The mean height was $157.18 \pm$ $8.14 \mathrm{cms}$ and the mean BMI was $22.28 \pm 4.12$. More than half of the students (58.08\%) had their BMI in the normal limits (Table 1).

$27.15 \%$ of the students have their family income between Rs. 20,000 - 49,999 and $24.4 \%$ of the students have their family income between Rs.10,000-19,999. 27.15\% of the student's head of their families are graduates and majority of the head of their families (67.35\%) are selfemployed (Table 2).

Majority of the students $(68.73 \%)$ have their menstrual flow ranging between 3-5 days and $65.64 \%$ of them have moderate amounts of menstrual flow (3-5 pads/days) (Table 3). 49.83\% have moderate levels
Table 1: Anthropometric Measurements of the participants.

\begin{tabular}{cccc}
\multirow{3}{*}{ Weight } & & Number of students & $\%$ \\
& $<50 \mathrm{~kg}$ & 133 & $45.70 \%$ \\
& $51-60 \mathrm{~kg}$ & 86 & $29.55 \%$ \\
& $61-70 \mathrm{~kg}$ & 50 & $17.18 \%$ \\
Height & $>70 \mathrm{~kg}$ & 22 & $7.56 \%$ \\
& $<150 \mathrm{~cm}$ & 44 & $15.12 \%$ \\
& $151-160 \mathrm{~cm}$ & 160 & $54.98 \%$ \\
& $161-170 \mathrm{~cm}$ & 71 & $24.40 \%$ \\
& $>170 \mathrm{~cm}$ & 16 & $5.50 \%$ \\
& Under weight & 51 & $17.53 \%$ \\
& Normal & 169 & $58.08 \%$ \\
& Over weight & 56 & $19.24 \%$ \\
& Obese & 15 & $5.15 \%$
\end{tabular}

BMI: Body mass index

Table 2: Family income and education status.

\begin{tabular}{|c|c|c|c|}
\hline & & $\begin{array}{l}\text { Number of } \\
\text { students }\end{array}$ & $\%$ \\
\hline \multirow[t]{7}{*}{ Monthly family income } & Less than Rs.1,000 & 22 & $7.56 \%$ \\
\hline & Rs.1,000-2,499 & 16 & $5.50 \%$ \\
\hline & Rs.2,500-4,999 & 14 & $4.81 \%$ \\
\hline & Rs.5,000-9,999 & 22 & $7.56 \%$ \\
\hline & Rs.10,000-19,999 & 71 & $24.40 \%$ \\
\hline & Rs.20,000-49,999 & 79 & $27.15 \%$ \\
\hline & More than Rs.50,000 & 67 & $23.02 \%$ \\
\hline \multirow{5}{*}{$\begin{array}{c}\text { Education qualification of } \\
\text { Head of the Family }\end{array}$} & Illiterate & 22 & $7.56 \%$ \\
\hline & Primary & 68 & $23.37 \%$ \\
\hline & High school & 59 & $20.27 \%$ \\
\hline & Higher Secondary & 63 & $21.65 \%$ \\
\hline & $\begin{array}{c}\text { Graduation and } \\
\text { above }\end{array}$ & 79 & $27.15 \%$ \\
\hline \multirow{5}{*}{$\begin{array}{l}\text { Employment of Head of } \\
\text { the Family }\end{array}$} & Self-employed & 196 & $67.35 \%$ \\
\hline & Govt employee & 30 & $10.31 \%$ \\
\hline & Agriculture & 8 & $2.75 \%$ \\
\hline & Private employee & 34 & $11.68 \%$ \\
\hline & Others & 23 & $7.90 \%$ \\
\hline
\end{tabular}

of perceived stress (Table 4). 66.7\% people of high stress levels are associated with heavy menstruation, which was significant wit $\mathrm{p}$ value of 0.001 (Table 5).

\section{DISCUSSION}

In the present study, we evaluated the association between the menstrual flow, BMI levels, socio-economic status and stress levels among young college students. Lower educational accomplishment students and lower strata socio-economic status students have been associated with higher odds of menstruation problems and perceived stress levels, which was in accordance with as study conducted by Kwak et al. ${ }^{[2]}$ These findings can facilitate the development and implementation of health improvement programs targeted for women with menstruation problems and higher stress levels based on their socio-economic status. 
Table 3: Information regarding menstrual flow of study participants.

\begin{tabular}{|c|c|c|c|}
\hline \multirow[t]{4}{*}{ Duration of Flow (Days) } & Less than 2 days & 17 & $5.84 \%$ \\
\hline & 3-5 days & 200 & $68.73 \%$ \\
\hline & 5-7 days & 69 & $23.71 \%$ \\
\hline & More than 7 days & 5 & $1.72 \%$ \\
\hline \multirow[t]{3}{*}{ Amount of Flow } & Mild ( $\leq 2$ Pads/days) & 85 & $29.21 \%$ \\
\hline & $\begin{array}{c}\text { Moderate (3-5 Pads/ } \\
\text { days) }\end{array}$ & 191 & $65.64 \%$ \\
\hline & $\begin{array}{c}\text { Heavy ( } \geq 6 \text { Pads/ } \\
\text { days) }\end{array}$ & 15 & $5.15 \%$ \\
\hline \multirow{2}{*}{$\begin{array}{c}\text { Passage of clots during } \\
\text { menses }\end{array}$} & Yes & 144 & $49.48 \%$ \\
\hline & No & 147 & $50.52 \%$ \\
\hline
\end{tabular}

Table 4: Perceived stress scores of study participants.

$\begin{array}{ccc}\text { Level of PSS } & \text { Number of students } & \% \\ \text { Low } & 93 & 31.97 \% \\ \text { Moderate } & 145 & 49.83 \% \\ \text { High } & 53 & 18.21 \% \\ \text { Total } & 291 & 100.00 \%\end{array}$

PSS: Perceived stress scale.
Students with higher BMI values will have elevated levels of insulin and testosterone, and a free androgen index, whilst the levels of SHBG will be decreased, leading to the hormonal changes that can cause menstrual irregularities and increased stress levels. ${ }^{[25]}$ Essentially, the socioeconomic status and obesity show an inversely proportional association in the developing countries leading to the increased concern. Hence, obesity in women with a low socio-economic status pose a risk for irregular menstruation and higher levels of perceived stress. ${ }^{[26]}$

Through the findings of this study, we recommend for efforts to educate patients on reproductive health, perceived stress and irregular menstruation, and the importance of early diagnosis and treatment must be informed.

\section{CONCLUSION}

This study revealed the relationship between socio-economic status (SES), body mass index (BMI), menstrual problems and psychological stress, which could be partly due to emotional eating as a coping strategy to overcome the psychological stress. By this study, we suggest for effective psychological interventions that can play an important role in maintain overall health of a female student and weight-management strategies, focusing on lower SES populations.

\section{CONFLICT OF INTEREST}

The authors declare that they have no conflict of interest.

Table 5: Association between perceived stress scores and menstrual history.

\begin{tabular}{|c|c|c|c|c|c|c|c|c|c|c|}
\hline \multirow{2}{*}{\multicolumn{2}{|c|}{ Menstrual cycle }} & & \multicolumn{8}{|c|}{ Level of PSS score } \\
\hline & & \multicolumn{2}{|c|}{ Low } & \multicolumn{2}{|c|}{ Moderate } & \multicolumn{2}{|c|}{ High } & \multirow{2}{*}{$\mathrm{n}$} & \multirow{2}{*}{$\begin{array}{c}\text { Chi-square } \\
\text { test }\end{array}$} & \multirow{2}{*}{$\mathbf{P}$} \\
\hline & & $n$ & $\%$ & n & $\%$ & $\mathrm{n}$ & $\%$ & & & \\
\hline \multirow{5}{*}{$\begin{array}{l}\text { Average } \\
\text { length of } \\
\text { menstrual } \\
\text { cycle }\end{array}$} & 21- 24 days & 17 & $35.42 \%$ & 30 & $62.50 \%$ & 1 & $2.08 \%$ & 48 & \multirow{5}{*}{20.63} & \multirow{5}{*}{0.01} \\
\hline & 25-28 days & 49 & $40.50 \%$ & 49 & $40.50 \%$ & 23 & $19.01 \%$ & 121 & & \\
\hline & 29-32 days & 19 & $21.84 \%$ & 49 & $56.32 \%$ & 19 & $21.84 \%$ & 87 & & \\
\hline & $>32$ days & 8 & $22.86 \%$ & 17 & $48.57 \%$ & 10 & $28.57 \%$ & 35 & & \\
\hline & No & 70 & $35.71 \%$ & 100 & $51.02 \%$ & 26 & $13.27 \%$ & 196 & & \\
\hline \multirow{4}{*}{$\begin{array}{l}\text { Duration } \\
\text { of Flow } \\
\text { (Days) }\end{array}$} & Less than 2 & 4 & $23.53 \%$ & 9 & $52.94 \%$ & 4 & $23.53 \%$ & 17 & \multirow{4}{*}{20.06} & \multirow{4}{*}{0.01} \\
\hline & 3-5 years & 75 & $37.50 \%$ & 99 & $49.50 \%$ & 26 & $13.00 \%$ & 200 & & \\
\hline & 5-7 years & 13 & $18.84 \%$ & 33 & $47.83 \%$ & 23 & $33.33 \%$ & 69 & & \\
\hline & More than 7 & 1 & $20.00 \%$ & 4 & $80.00 \%$ & 0 & $0.00 \%$ & 5 & & \\
\hline \multirow[t]{3}{*}{$\begin{array}{l}\text { Amount of } \\
\text { Flow }\end{array}$} & $\begin{array}{c}\text { Mild ( } \leq 2 \text { Pads/ } \\
\text { days) }\end{array}$ & 24 & $28.24 \%$ & 46 & $54.12 \%$ & 15 & $17.65 \%$ & 85 & \multirow{3}{*}{26.76} & \multirow{3}{*}{0.001} \\
\hline & $\begin{array}{c}\text { Moderate (3-5 } \\
\text { Pads/days) }\end{array}$ & 68 & $35.60 \%$ & 95 & $49.74 \%$ & 28 & $14.66 \%$ & 191 & & \\
\hline & $\begin{array}{l}\text { Heavy ( } \geq 6 \\
\text { Pads/days) }\end{array}$ & 1 & $6.67 \%$ & 4 & $26.67 \%$ & 10 & $66.67 \%$ & 15 & & \\
\hline \multirow{2}{*}{$\begin{array}{l}\text { Passage } \\
\text { of clots } \\
\text { during } \\
\text { menses }\end{array}$} & Yes & 28 & $19.44 \%$ & 84 & $58.33 \%$ & 32 & $22.22 \%$ & 144 & \multirow[t]{2}{*}{20.63} & \multirow[t]{2}{*}{0.001} \\
\hline & No & 65 & $44.22 \%$ & 61 & $41.50 \%$ & 21 & $14.29 \%$ & 147 & & \\
\hline
\end{tabular}

$\mathrm{P}<0.05$ was considered to be statistically significant. PSS: Perceived stress scale. 


\section{ABBREVIAITONS}

HPA Axis: Hypothalamic-Pituitary-Adrenal Axis; SHBG: Sex Hormone-Binding Globulin; FAI: Free Androgen Index.

\section{REFERENCES}

1. Rahman I, Akesson A, Wolk A. Relationship between age at natural menopause and risk of heart failure. Menopause. 2015;22(1):12-6.

2. Mumford SL, Steiner AZ, Pollack AZ, Perkins NJ, Filiberto AC, Albert PS, et al. The utility of menstrual cycle length as an indicator of cumulative hormonal exposure. J Clin Endocrinol Metab. 2012;97(10):E1871-9.

3. Attarchi M, Darkhi H, Khodarahmian M, Dolati M, Kashanian M, Ghaffari M, et al. Characteristics of menstrual cycle in shift workers. Glob J Health Sci. 2013;5(3):163-72.

4. Voorhis BJV, Santoro N, Harlow S, Crawford SL, Randolph J. The relationship of bleeding patterns to daily reproductive hormones in women approaching menopause. Obstet Gynecol. 2008;112(1):101-8.

5. Solomon CG, Hu FB, Dunaif A, Rich-Edwards J, Willett WC, Hunter DJ, et al Long or highly irregular menstrual cycles as a marker for risk of type 2 diabetes mellitus. JAMA. 2001;286(19):2421-6.

6. Wei SY, Schmidt MD, Dwyer T, Norman RJ, Venn AJ. Obesity and menstrual irregularity: Associations with SHBG, testosterone, and insulin. Obesity. 2009;17(5):1070-6

7. Nishikitani M, Nakao M, Tsurugano S, Inoure M, Yano E. Relationship between menstruation status and work conditions in Japan. Biopsychosoc Med. 2017; $11(1): 26$

8. Rafique N, Al-Sheikh MH. Prevalence of menstrual problems and their association with psychological stress in young female students studying health sciences. Saudi Med J. 2018;39(1):67-73.

9. Loucks AB, Thuma JR. Luteinizing hormone pulsatility is disrupted at a threshold of energy availability in regularly menstruating women. J Clin Endocrinol Metab. 2003;88(1):297-311.

10. Part J, Suh S, Kim K, Kim H. Female workers' attitudes toward menstruation, premenstrual discomfort and coping method. J Korean Soc Matern Child Health. 2012;16(1):100-12

11. Amu EO, Bamidele JO. Prevalence of menstrual disorders among adolescent girls in Osogbo, South Western Nigeria. Int J Adolesc Med Health. 2014;26(1):101-6.

12. Bitzer J, Tschudin S, Stadlmayr W. Menstruation and its impact on women's health. Zentralbl Gynakol. 2005;127(5):282-7.

13. Singh $\mathrm{R}$, Sharma $\mathrm{R}$, Rajani $\mathrm{H}$. Impact of stress on menstrual cycle: A comparison between medical and non-medical students. Saudi J Health Sci. 2015:4(2):1159

14. Rowland AS, Baird DD, Long S, Wegienka G, Harlow SD, Alavanja M, et al. Influence of medical conditions and lifestyle factors on the menstrual cycle. Epidemiology. 2002;13:668-74.

15. Kim TH, Park HS, Lee HH, Chung SH. Premenstrual syndrome and dysmenorrhea in the career women at Bucheon City. Korean J Obstet Gynecol. 2011;54(9):523-8

16. Kaplan JR, Manuck SB. Ovarian dysfunction, stress, and disease: A primate continuum. ILAR J. 2004;45(2):89-115

17. Nisar N, Zehra N, Haider G, Munir AA, Sohoo NA. Frequency, intensity and impact of premenstrual syndrome in medical students. J Coll Physicians Surg Pak. 2008;18(8):481-4.

18. Laaksonen M, Talala K, Martelin T, Rahkonen O, Roos E, Helakorpi S, et al. Health behaviours as explanations for educational level differences in cardiovascula and all-cause mortality: A follow-up of 60000 men and women over 23 years. Eur J Public Health. 2008;18(1):38-43.

19. Langhammer A, Krokstad S, Romundstad P, Heggland J, Holmen J. The HUNT study: participation is associated with survival and depends on socio-economic status, diseases and symptoms. BMC Med Res Methodol. 2012;12(1):143.

20. Dowd JB, Zajacova A. Does the predictive power of self-rated health for subsequent mortality risk vary by socio-economic status in the US?. Int J Epidemiol. 2007;36(6):1214-21.

21. Münster K, Schmidt L, Helm $P$. Length and variation in the menstrual cycle-a cross-sectional study from a Danish county. Br J Obstet Gynaecol. 1992;99(5):422-9.

22. Klemetti R, Raitanen J, Sihvo S, Saarni S, Koponen P. Infertility, menta disorders and well-being-a nationwide survey. Acta Obstet Gynecol Scand. 2010;89(5):677-82.

23. Cohen S, Kamarck T, Mermelstein R. A global measure of perceived stress. J Health Social Behav. 1983;24:385-96.

24. Kwak $Y$, Kim $Y$, Baek KA. Prevalence of irregular menstruation according to socio-economic status: A population-based nationwide cross-sectional study. PLoS One. 2019:14(3):e0214071.

25. Wei SY, Schmidt MD, Dwyer T, Norman RJ, Venn AJ. Obesity and menstrual irregularity: Associations with SHBG, testosterone, and insulin. Obesity. 2009;17(5):1070-6.

26. Kaplan JR, Manuck SB. Ovarian dysfunction, stress, and disease: A primate continuum. ILAR J. 2004;45(2):89-115.

Cite this article: Panneerselvam P, Suganthi V, Karuppiah P, Subramanian S, Sasikala G, Easwaarisiva R. Association of BMI, Menstrual Flow, Socio-economic and Educational Status with Psychological Stress Levels in Young Age Students. Int J Clin Exp Physiol. 2021;8(1):7-10. 